VS Publications

Alford Council of International English \& Literature Journal(ACIELJ)

Impact Factor:4.401(SJIF)An International Peer-Reviewed English Journal

www.acielj.com

Vol-3,Issue-2 ,2020

ISSN:2581-6500

\title{
DIVERSE DIMENSION IN JHUMPA LAHIRI'S THE LOWLAND
}

Dr. Y. Jayanthi ${ }^{1}$

Asst. Professor in English

RBVRR Women's College

Narayanaguda, Hyderabad.

\author{
Ms. M. Suchitra Reddy ${ }^{2}$ \\ HOD, Dept. of English, \\ RBVRR Women's College \\ Narayanaguda, Hyderabad
}

\begin{abstract}
:
Literature is a culmination of varied ideas, opinions, and views uniquely portrayed by the writers as per their notions and nations. There is an augmented difference in the themes depicted by the pre-Independence women, were very contemporary on the clash between tradition and modernity, women's struggle for empowerment and

writings are simple, and realistic with a universal appeal. Being a second generation immigrant born to the parents, Lahiri has witnessed the agonies of "displacements" and depicted in her works the feelings of the characters with penetrating insight. The main objective of the paper is to present a diverse dimension of the Diaspora in one of the novels of JhumpaLahiri's, “The Lowland."
\end{abstract} psychological turmoil in a patriarchal milieu. Still with their persistent quest and zeal crossed all the barriers and scaled great heights on par with men. On the themes chosen by woman writers had opened new doors to many upcoming writers. The writers of the next generation such as Kamala Markandaya, Ruth PrawarJhabvala, NayantaraSahgal, Uma Vasudev, Anita Desai, Bharati Mukherjee, Shashi Deshpande, Arundhati Roy, Chitra Banerjee Divakaruni and JhumpaLahiri represent a new era of emancipation for women with increased opportunities, and dynamic participation in the social and intellectual life. JhumpaLahiri is one of the significant Indo-Anglian Expatriate writers who have contributed profusely to the diasporic literary tradition. Lahiri's works are mostly based on the first and second generation Indians depicting their emotional turmoil and psyche. Her
Keywords:Literature, Women Writers, Variation of Themes, Diaspora, Displacedness, Bengali Culture, Immigration, Powerful Weapon, Diverse Dimension, the Lowland, Gauri

\section{Introduction}

The dawn of self-awareness in a society, long suppressed under the British rule, provided variety of themes to the novelists and compelled them to think anew about the numerous social and national problems. In fact, at this period the Indian English novel discovered some of its most significant themes in the novels of the pre-independent period: freedom struggle, East-West relationship, quest for identity. It must be admitted that attempts were made to depict life of the day in the 
VS Publications

Alford Council of International English \& Literature Journal(ACIELJ)

Impact Factor:4.401(SJIF)An International Peer-Reviewed English Journal

www.acielj.com

Vol-3,Issue-2,2020

ISSN:2581-6500

novels that were far being satisfactory and highly realistic. The novelists of preindependence had tried to make their stories to the readers as realistic as possible. As the novelists do not restrict themselves to a single element to narrate in their novels, they delineated the varied communities and caste, various regions and cultural segments; they interpreted nearly every aspect of India's variegated life and infinite aspects.

Post-Independence India witnessed apparent changes, sporadic authors, and the writers had taken the task to be conscious of social norms, on their shoulders. The other interesting feature of this period is: it had given birth to the Indian, "Diaspora" with clusters unsuccessful at identifying themselves with the native mode of administration, migration to another land which was once called the "white master's." The abstract anxiety of helplessness, the angry young man restlessness were the marked features of every Independent Indian human mind in the core of literature, which however had taken towards fresh directions under the gradual arriving of globalization and its influence on Indian literature.

\section{Women writers}

Women were educated after many reforms, which opened vistas to liberate themselves and walk into different realms on the society. Their thirst for knowledge and yearning for identity stirred up as their latent abilities, and potentialities came to the forefront. In English Literature, the First Woman Writer wasAphraBehn born in 1640 in London. Ben was the first women novelist, dramatist, poet and a playwright. Emergence of Women
Novelists from Post-Independence was a significant development in the Indian Writing in English. An interesting aspect of the modern Indian renaissance had been the creative release of feminine sensibility. The emergence of women writing was the similar development in Indian literature noticed in the society by breaking current hinges prevailing during that time. "Being a woman is a terribly difficult trade it consists of principally dealing with men." (Joseph Conrad, 2016)

The writers of the next generation such as Kamala Markandaya, Ruth PrawarJhabvala, NayantaraSahgal, Uma Vasudev, Anita Desai, Bharati Mukherjee, Shashi Deshpande, Arundhati Roy, Chitra Banerjee Divakaruni and JhumpaLahiri represent a new era of emancipation for women with increased opportunities, and dynamic participation in the social and intellectual life. They continued their quench for writing with the same inspiration from the early writers without hiatus.

\section{The Contemporary Woman Writers}

The contemporary woman writers articulated their ideas between men's liberation and independence with a great measure of strength, dignity and passion. They highlighted on identity crises, loneliness, poverty, racial discrimination, social realism and search for home also finds expression within the domain of their works differently discussed by a plethora of writers. In the modern fiction, "selfexpression" was remarkable; claimed by the female protagonist as her birthright, the liberty and free will that embossed in their fiction. To what was expressed by Lord Tennyson, in, "Princess," women writers proved it wrong by rendering their 
VS Publications

Alford Council of International English \& Literature Journal(ACIELJ)

Impact Factor:4.401(SJIF)An International Peer-Reviewed English Journal

www.acielj.com

Vol-3,Issue-2,2020

ISSN:2581-6500

excellent contribution towards literary works with robust energy, optimism and bagged several astonishing awards of their success. "Man for the field and woman for the hearth: Man for the sword and for the needle, she: Man with the head and woman with the heart: Man to command and woman to obey; All else confusion." (Dr. Viswanath Bite, 2015:01)

\section{JhumpaLahiri}

JhumpaLahiri

(1967):

NilanjanaSudeshnaLahiri, is born in London to Bengali parents and was popularly known as JhumpaLahiri with the family nick name, "Jhumpa." Lahiri moved to the United States with her family at the age of three. Lahiri was grown in Rhode Island and pursued her studies. Lahiri was given the Pulitzer Prize for Interpreter of Maladies (1999) and PEN/ Hemingway Award. Lahiri's popular works were Interpreter of Maladies (1999), The Namesake (2003), Unaccustomed Earth (2008) and The Lowland (2013).

\section{Lahiri's Themes}

Lahiri's choice of themes are universal like marital harmony, loss of a loved one or parenting which make her narratives easily consumable by various categories of readers. Furthermore, her choice of genres allows for a mixture of heterogeneous perspectives even from within an apparently homogeneous community. Lahiri portrays repeatedly Indian/Bengali culture to meet international wide and thus, opens up her literary creations to a wider audience and explores new cultural territories. Her female protagonists constantly find comfort in the alien land with the local identification that ultimately gives them the solution. "I feel partly American, but I have an ambiguous relation with both America and India, the only two countries I really know. I never feel fully one way or the other."

Lahiri portrays a vivid picture of the lives of immigrants in her short stories, and novels. Her characters are real life people who experience all human emotions both positive and negative. Amitav Ghosh, says that, "JhumpaLahiri has opened up a new vista for Indian Writing in English."(Alessandro Monti RK Dhawan, 2002:165)

The Lowland

JhumpaLahiri's fourth book, and the second novel, The Lowland (2013), is a different genre of Lahiri's works. Her writing style is versatile and takes her readers to a different world. She chooses the ethos and the political history to depict, exhibiting neither imaginative curiosity nor genuine sympathy to her characters. Lahiri, with intense knowledge on a new subject "Naxalbari" depicts the novel in a new dimension. The Naxalite movement is the central to the plot, have maintained a noticeable presence in India. It began in 1967 with a peasant uprisings in Naxalbari, a village in northern Bengal near the Nepali border. The actions of the characters are often shaped by this movement. In fact, the characters that remain untouched by Naxalism represent the precision and care that has long been characteristic of Lahiri's fiction.

The Lowland is based on a real incident that took place quite some years before in Lahiri's life, which is mentioned in an interview: "The tragic incident that she first heard about in India, during one 
VS Publications

Alford Council of International English \& Literature Journal(ACIELJ)

Impact Factor:4.401(SJIF)An International Peer-Reviewed English Journal

www.acielj.com

Vol-3,Issue-2,2020

ISSN:2581-6500

of her many visits while she was growing up in 1972/73: two young brothers, who had become involved in a violent political movement, were executed just a few hundred yards from her grandparents' home in Calcutta." (JhumpaLahiri, 2014)

Lahiri presents the novel by giving a crystal clear outline to the readers; like an eye for detail and an ear to listen. Subhash and Udayan are biological brothers and have a strong bondage with each other though their ideology is in contrast. Udayan, joins the Naxalite movement in the 1960s. Caught in the midst of the communist movement taking place in the West Bengal, Udayan is eventually executed by the police for his involvement in the Naxalite movement. His sibling Subhash, returns from US, hoping to pick up the pieces of the shattered family, and marries Udayan's widow Gauri, out of a sense of duty. He takes Gauri to Rhode Island with him to liberate her, although she is pregnant with his brother's baby.

Lahiri meticulously deals with the Indian attitude of shouldering responsibility through Subhash. On the other side, Gauri transforms herself so much to an extent where she abandons her twelve-year-old child, Bela and Subhash, searching for her a new life. But at last, she could not succeed in eliminating past from her memory. There is redemption of all characters in the end.

Lahiri, with deep insight; starts the novel by Udayan's habit of "jumping," followed by a series of actions related to "jump" at the time of the police arrest. Symbolically he "jumps" from many of his responsibilities; to take care of his parents, his wife and the due child.
Lahiri probed into the deeper layers of human heart through own observation in portraying the two own brothers and how their paths two are different: "Siblings are like branches of a tree, we all grow in different directions yet our roots remain as one."(P. Saleema, 2001: 64)

Letters are the means of communication for Subhash and Udayan. He receives a letter from Udayan and feels their love for each other once more; their affection stretched half-way across the world. Yet, "stretched to the breaking point by all that now stood between them." (JhumpaLahiri, 2013:43) The second letter informs Subhash of Udayan's marriage to Gauri, sister of Manish whom he befriends in Naxalite movement and his deeper involvement in Naxalite, activities without his parents knowledge. They are responsible for "sadistic, gruesome" (JhumpaLahiri, 2013:87) killings of unarmed traffic constables, affluent businessmen, members of rival parties, and even educators.

\section{Diverse Dimension}

GauriLahiri's woman protagonist Gauri is dissimilar to her other protagonists. She is remarkably an interesting character of Lahiri's. Gauri is not only active in Naxalbari, but also helps her husband Uday in killing the Police Constable.

Subhash receives the tragic news of his brother's death and leaves for India. On reaching home, he meets his parents whose faces convey disappointment, "calloused by grief, blunted by what no parent should have seen" (JhumpaLahiri, 2013:91). Subhash finds the city without many changes in contrast to his life in America where he had recurrent changes. Calcutta, the "city with nothing, with everything" 
VS Publications

Alford Council of International English \& Literature Journal(ACIELJ)

Impact Factor:4.401(SJIF)An International Peer-Reviewed English Journal

www.acielj.com

Vol-3,Issue-2,2020

ISSN:2581-6500

(JhumpaLahiri, 2013:89) is unchanged. He observes the ill-treatment of his parents towards Gauri who is pregnant; and decides to take her to a place where nobody knows the painful truth, and they could be a family.

The bond between Subhash and Gauri is "a shared awareness of the person they'd both loved" (JhumpaLahiri, 2013:115). They are connected by the past and project a future together, although they do not share a love in the present. Subhash shoulders the responsibility of his brother's wife, Gauri. "Besides, I seemed to hold two lives-the life of thought, and that of reality; and, provided the former was nourished with a sufficiency of the arrange necromantic joys of fancy, the privileges of the latter might remain limited to daily bread, hourly work, and roof of shelter." (Jeremy Hawthron, 1983:75)

Gauri reaches US burdened with the horrifying image of Udayan's shot by the police and ensuing nightmares of the death of him. Marriage becomes an obligation for her to honour to escape from her "past" and to embark on a "fresh" life. Lahiri presents purpose on "marriage" differently in the case of Gauri, who marries Subhash as a way of staying "in touch" with her lost love. Once she marries Subhash and moves to Rhode Island, her character becomes increasingly opaque. She carries the future inside her, but is keenly aware she cannot free herself of Udayan's memory: "She felt as if she contained a ghost .. Both within her and remote.” (JhumpaLahiri, 2013:124)
Though getting placed in a completely contrasting locale, Gauri is unable to let go off the past. Indeed, even on the plane "it was time, not space, she'd been aware of travelling through." (JhumpaLahiri, 2013:125)

Gauri ferociously delimits herself from Indian patterns of femininity; in Rhode Island from stifling cultural norms. She has two choices; one either she has to disappear from the social scene or invent a new identification for herself. Education is a weapon in the hands of Gauri which emancipates her; and, she succeeds in creating her space in which to indulge repressed aspects of her personality, an inner space that performs the same function from a woman, attending to the needs of Subhash and Bela; the outer space going to college and flourishing in her career. She thrives professionally in the United States and travels around the world to attend various conferences. Lahiri uses, "immigration" as a weapon into her hands which empowers and enables Gauri to become a transnational citizen. She resembles one of the most powerful characters of Bharati Mukherjee's novel Jasmine. "There are no harmless compassionate ways to remake ourselves, we murder who we were, so we can rebirth ourselves in the image of dreams." (Bharati Mukherjee, 1989:25)

Gauri sees the ideological retreat from the implications of what has been discovered in America; and, she accepts it more impressively by taking a decision to move to California and dedicates herself to teaching, and doing research, abandoning her twelve-year-old, Bela. Running away 
VS Publications

Alford Council of International English \& Literature Journal(ACIELJ)

Impact Factor:4.401(SJIF)An International Peer-Reviewed English Journal

www.acielj.com

Vol-3,Issue-2,2020

ISSN:2581-6500

from her daughter and not contacting her for over two decades throw light on her severe attempts to run away from the past. Every action of hers is an attempt to escape from the loop of time. "Neither completely at one with the new selecting nor fully disencumbered of the old, beset with half involvements and halfdetachments, nostalgic and sentimental on one level, an adept mimic or a secret outcast on another." (Alessandro Monti RK Dhawan, 2002:239)

Gauri's timeline only includes the past and the future, eluding the present. To the right she sees the recent past, the year she had met Udayan, the year she was born, 1948, "prefaced by all the years, and centuries that came before." (JhumpaLahiri, 2013:110-111) To the left she sees the future, "the place where her death, unknown but certain, was end point." (JhumpaLahiri, 2013:111)

Gauri remains undaunting and emerges as a towering figure of compassion, endurance, and dignity. She does not succumb herself to the family obligations of paying attention to either Bela or Subhash. Gauri feels Bela is a burden to her, and she prevents her from studying. She does not complain to Subhash about her life with him, but she seems incapable of loving him or Bela whole-heartedly. In fact, "it was as if she'd reversed their roles, as if Bela were a relative's child and not her own." (JhumpaLahiri, 2013:159)

Lahiri portrays "motherhood" from different dimensions: Motherhood restricts, inhibits, and impairs Gauri. So, she flees and rids herself of it, the way she frees herself of her long hair and saris. She never regrets the new look, and the independence that immigration brings her; in later years she regrets cutting her connection with Bela.

Gauri moves around freely, takes up teaching jobs in Santa Cruz and San Francisco; and, she has a good relationship with her colleagues and students. Gauri's intend to move close to her student implies the displacement from her family.Lahiri gives Gauri a dual role; as Udayan's widow she becomes Subhash's wife. As Bela's mother she abandons her daughter and behaves like a "childless woman." (JhumpaLahiri, 2013:240) Walking away from Bela does not turn out to be redemption. Instead, she often searches on the Internet for traces of Udayan and Bela. She expresses her disappointment over the realization of her fatal mistake. The realization that dawn upon her demonstrates how unwise she has been in not taking an appropriate step. The fatal realization of Gauri leaves her at the cross roads.

For once, time starts to move forward for all the three characters: Gauri envisions a future relationship with her granddaughter; Subhash starts to travel with his new wife, Elise; and, Bela commits herself to a romantic relationship with Drew, leaving the door slightly open for a possible reconciliation with the mother who had rejected her in her childhood. Lahiri ends the novel with a happy note, leaving Gauri in her own space to meet her pursuits.

\section{Conclusion}

JhumpaLahiri presents Gauri character in a unique manner unlike the other characters in her collection of short stories, and a novel. Many characters are 
VS Publications

Alford Council of International English \& Literature Journal(ACIELJ)

Impact Factor:4.401(SJIF)An International Peer-Reviewed English Journal

www.acielj.com

Vol-3,Issue-2,2020

ISSN:2581-6500

presented in a docile manner whereas

Gauri is portrayed in a dynamic way.

Gauri is not sentimental; she is strong and plays her role with robust enthusiasm. Gauri is happy to reinvent herself professionally. She is not contented with her personal life as she is secluded from her family members. JhumpaLahiri is the most distinguished writers of Indian diaspora. She has carved a niche for her characters. The variety of Lahiri's characters allows one to recognize the distinct differences in the characteristic quality of women. The characters in Lahiri's fiction try to transcend the boundaries and break the norms to liberate themselves. A gallery of memorable characters indulges in their idiosyncrasies to the enhancement of their enjoyment. They live in our memory because of they are uncanny ability to rise above the mundane with their vivid reactions to lifereactions that are fixed in the framework of the plausible and yet merge in the region of fantastical. The expatriate experience is differently encumbered in the characters. Lahiri with her dexterity has presented the changing moods of the characters. Lahiri stands out even among the Diaspora writers with her realistic characterisation and topical thematic exploration. She occupies an important place in expatriate Diaspora.

\section{References}

[1]Conrad, Joseph. The Hindu. 21st March 2016.

[2]Dr. Bite, Viswanath. The Criterion. An International Journal in English, Vol.6, Issue-4, 2015. P. 01 .
[3]Hawthron, Jeremy. Multiple

Personality and Disintegration of Literary Character. New York: St. Martin's Press, 1983. Pg. 75.

[4]https://www.brainyquote.com/q uotes/jhumpa_lahiri_759652 3.

[5]Lahiri,Jhumpa on her interaction with Audience in Jaipur Literary Festival on her debut Novel Interpreter of Maladies. 2014.

[6]Lahiri, JhumpaThe Lowland. New York: Random House, 2013. [7]Monti Alessnadro, Dhawan R K. Discussing Indian Woman Writers Some Feminist Issues. New Delhi: Prestige Publications, 2002. Pg. 165.

[8]Monti Alessnadro, Dhawan R

K. Discussing Indian Woman Writers Some Feminist Issues. New Delhi: Prestige Publications, 2002. Pg. 239.

[9]Mukherjee, Bharati. Jasmine, New York: Grove, 1989. Pg.25.

[10]Saleema, P. The Novels of Shobhaa De and Bharati Mukherjee Emergence of the New Woman, New Delhi: Prestige Books International, 2001. Pg. 64. 